\title{
Quality of Work Life on Performance Management
}

\author{
Angeline Atieno Oyomo \\ Moi University \\ School of Human Resource Development \\ Department of Development Studies, Eldoret, Kenya
}

\begin{abstract}
Worldwide, Quality of work life (QWL) has been viewed to include some objective and subjective factors which may condition operations and other inner aspects concerning the quality of relationships and methods of management. The study analyzes the quality of work life indicators in a cohort of department of health workers. Semistructured interviews were conducted, to assess the quality of work life through the identification of the most important indicators and to evaluate the degree of Career Care Programs and the importance of each indicator. Target population was 300 employees with sample size of 180 . The study pointed out some macro areas which are relevant to define work life quality of the analysed sample: relationships with colleagues, work organization, taking care of clients, professional ability and professional growth. The agile work environment, performance management, Social Service Care and the management styles seem to be important to determine the differences among the workers in the quality perceived in their work life. However, the study found out that there is low esteem among employees owing to the poor social service care, biased performance management and non-motivating reward systems. This could explain why employees come to work late and leave early yet at some point they are not in the office doing their personal activities during work time.
\end{abstract}

Keywords: Agility Working Environment, Social Service Care, Self Care Program, Career Care Program and Performance Management

\section{INTRODUCTION}

Environment in which high level performance is achieved can be identified. Although this is hard to achieve but most managers struggle to ensure they control various factors that affect their organisational performance. Yet performance management is still an uphill task to most managers. Quality of Work Life (QWL) is a state of equilibrium in which the demands of both a person's job and personal life are equal (Abercromby, 2007). It is the ability to effectively manage the juggling act between paid work and the other activities, that are important to people. At present, work environment has become more stressful because of diverse role expectations, cut throat competition, globalization and technological innovations. Such changes have created several complications on both the domestic and professional fronts of the employees (Allen, Herst, Bruck, \& Sutton, 2010). The pressure of work has been intensifying and there is growing feeling among employees that the demands of work begin to dominate life and sense of work life balance is felt. The challenge of integrating work and family life is a part of everyday reality for the majority of employees now-a-days (Delecta, 2011).

High performance management is the heartbeat of a successful business. When employees are distracted and unhappy, their work suffers, and ultimately so does the company. When employees experience problems, they do not perform to their highest potential. Troubled employees often call in sick or are not mentally present when they attend work (Oswald, 2012). Understand the top factors of employee unhappiness and offer appropriate assistance if 
needed. Problems such as financial stress, job stress, marriage and relationship as well as lack of pride and prestige of joyous life are affecting modern employees (Patrick, 2016).

These organisations are increasingly realizing that such practices are stressing employee physical health and pushing their lives into chaos. Eventually employees lose pleasure in their work and productivity drops. While work life balance (QWL) can be a useful tool to drive forward creation of environment that enhances the optimum level of satisfaction between work and non-work essentials, its practicability is inadequate. Apart from that, most organisations present an environment where employees must wait until the end of the workday, week, or even career to actually start living. These organisations lack drivers that can make work full of pleasure and meaning that it blends in beautifully with all aspects of employee lives (Allen \& Russell, 2009).

Yet performances of such organisations are not improving commensurate with these incentives. Moreover, many organisations suffer from the complexities of providing an environment that facilitate employee pride, satisfaction, happiness, celebration, love, a sense of well being, and all the joys of living. While work life balance (QWL) can be a tool useful in the understanding of enabling environment to offer means of employee-desired indicators, its applicability has been inadequate (Ng'ang'a, 2010). In other organisations, employees suffer from insufficient time off and an appropriate workload, lack of telecommuting, inflexible hours, and lack of wellness initiatives in the workplace such as yoga classes and mindfulness training. At the same time, the results-only workplace (ROWE), one approach to creating balance, allows employees to arrange their working lives in any way that suits them, as long as they complete the tasks they have been assigned are not adequately accessible to employees (Leblebici, 2012).

Most managers have struggled to achieve a balanced working environment that can drive performance. These efforts have proved futile as they continue to face stressed employees, employee lack of pride, poor desire to work, absenteeism, and other such challenges affecting productivity. The results achievable are discouraging. Yet productivity is the core aspect of performance in realising stable financial value, physical quantity, efficient and effectiveness in labour and capital (Morrissey \& Warner, 2011). Apart from that, most employees fail to attain better results since there is no concern to achievement and enjoyment consideration of employees on the side of employers. Most of the time the good results are celebrated by employers only leaving employees who worked hard for that results, while when there is poor productivity, employees become the subject of discussion and sometimes sackings.

However, many organisations are facing poor performance management (Thompson \& Prottas, 2016). Quality of Work Life is a means of finding easier ways to work, of getting tools to carve out the space to live a quality life, take care of personal responsibilities, and map out a healthier road to success. In our Quality of Work Life programs we bring your team the best strategies vetted by the research to stop doing things the hard way and start doing things the smart way. But available research studies share little on the application of work life balance an approach used by organizations to manage performance management (Wang \&Walumbwa, 2010).

As a result, initiatives such as flexible working hours, alternative work arrangements, leave policies and benefits in lieu of family care responsibilities and employee assistance programmes have become a significant part of most of the company benefit programmes and compensation packages (Hung, 2016). Effective work life balance may contribute to meeting organizational goals. In effect, well-balanced social and professional lifestyles of hardworking 
employees can produce desired company results and meet projected career goals (Owusu, 2014). The rationale underpinning this hypothesis is that, once the employee is given ample time with their families and friends, they become more focused on their professional and career goals, thereby achieving set goals within their organisations. On the other hand, when companies pressure employees to become workaholics without spending some of their time with families and friends, organizational results may suffer. The majority of studies investigating the outcomes of work-life practices does not measure work-life conflict, and thus cannot support this proposed mediated relationship (Ronen, Simcha; Primps \& Sophia, 2010).

Performance management is the heart and soul of any organization. Any successful business knows much of its success is due to diligent workers with excellent productivity. Employees who put forth extra effort often make a big difference in company profits. The employees who do only what the job duties require, and no more, can stymie the progress of a company. Increasing productivity is one of the most critical goals in business. Unfortunately, it's an activity seldom accepted by Human Resource professionals as a legitimate mandate. It is important to motivate all employees to reach their full potential and maximal their level of productivity. Companies that recognize and encourage increased productivity are likely to be more successful than their counterparts that don't (Oswald, 2012).

The resulting wealth is generated by the combined efforts of employee) and the employers. Value added is thus distributed as wages to employees, depreciation for reinvestment in machinery and equipment, interest to lenders of money, dividends to investors and profits to the organization.

\section{SIGNIFICANCE OF THE STUDY}

The concept of quality of life and quality of work life (QWL) are frequently adopted in research within health organizations while dealing with the subjects of wellness and professional satisfaction. Many studies have brought to light how the QWL is influenced both by the inner methods of management of the organization and by the external context where the organization operates; this may also influences the operating modalities.

This study helps enlighten management of various organizations of the various effects of worklife balance practices on the performance of employees in an organization. The study also brings out specifically, the work-life balance practices, which the institutions have been able to make available to employees. It also seeks to bring out the level of encouragement and motivation the institutions have given to employees to work effectively, among others. The importance of this study is therefore to highlight the various employee work-life balance practices and how it affects the productivity of an organization. This study will go a long way to illustrate how organizations should treat its employees' in-order to increase productivity.

The assumptions underpinning the practice of Human Resource Management are that people (employees) are the organisation's key resource, and organizational performance largely depends on their productivity. If, therefore, an appropriate range of Human Resource policies and processes are developed such that they are tailored to improve work life balance of employees, Human Resource will make a substantial impact on firm's performance.

\section{LITERATURE REVIEW}

Units; flexi-timing if supported by genuine reasons is critical for employees to improve on their productivity (Allen, 2009). While employees may earn more money and can afford more stuff, the organisation is definitely paid for it in terms of working longer hours, to the point of 
burnout and even beyond. The truth is most employees spend their entire earthly existence working for a life that they never truly enjoy.

In an ever-developing, fast-paced society, Agility working has never been more important. It is vital we meet the needs of the $21^{\text {st }}$ Century work environment as technology advances and the behaviours and expectations of customers and colleagues evolve. Agility working is at the heart of any organization to work more efficiently for the benefit of colleagues, customers and the business. Such organisations are committed to building a culture that encourages innovative Agility working policies and practices to bring both long lasting benefits, and to support colleagues to achieve true work life balance (Balmforth \& Gardner, 2012).

There are many different definitions for agility, but here we will emphasize on its concept more than its definitions. Agility started from production management field (Iacocca Institute, 1991a; 1991b) and then became prominent in the service field. As mentioned by Swafford, Ghosh, and Murthy, (2006), agility enables an organization to respond to environmental uncertainties and market volatility in a timely and effective fashion, allowing organizations to be able to establish a superior competitive position in their field of activity. There is, as yet, no universal definition available for agility and many scholars have discussed the ignored dimensions in different definitions of agility.

There are many different views on agility. As Sam-Bamurthy, Bharadwaj and Grover, (2003) explain, agility is comprised of three interrelated capabilities, namely customer agility, collaborating agility and Financial Value agility. Besides, there are also some emphases on knowledge in agility related literature.

A virtual organization is one where the core business processes are performed by using electronic media such as Internet. More specifically, a virtual university refers to a university, which offers higher education programs through electronic media, typically the Internet. As argued by Ca-Marinha-Matos et al. (2000), agility is an important requirement for successful organizations in periods of market turbulence and unpredictable socio-economic changes, and the concept of virtual enterprise embeds an implicit notion of agility in itself. Agility constitutes of three factors: agility drivers, which refer to changes and pressures of organization's environment that makes it necessary to search for new ways of running a business in order to maintain or achieve competitive advantage; agility capabilities, which are the essential capabilities that are needed in order to respond to changes and take advantage of them; and agility providers, which are the means through which an organizations can obtain capabilities (Zhang and Sharifi, 2000).

Sharifi and Zhang $(1999,2001)$ identified dynamic competitive pressure as one of the most important drivers of agility in any organization. Vázquez-Bustelo, Avella and Fernández, (2007) believe that turbulent environments influence agility. Besides, Yusuf and Adeleye (2002) viewed agility as a response to emerging requirements of sophisticated and changing consumers and products under persistently changing competitive and success factors. In this way, organisation can recognize the importance of agility and becoming agile in all organizations, especially in knowledge-based organizations, which undertake their activities in a dynamic and changing environment.

The role of work has changed throughout the world due to economic conditions and social demands. Originally, work was a matter of necessity and survival. Throughout the years, the role of work has evolved and the composition of the workforce has changed. Today, work still is a necessity but it should be a source of personal satisfaction as well. One of the vehicles to 
help provide attainment of personal and professional goals is work-life benefits and programs. Implementation of these programs differs depending on the nature of employee environment and the fundamental beliefs about the goals of such programs (Balmforth \& Gardner, 2012).

Quality of Work Life is meaningful achievement and enjoyment in everyday life." The primary way companies can help facilitate Quality of Work Life for their employees are through worklife programs and training. Achievement and enjoyment at work is a critical part of anyone's Quality of Work Life. Furthermore, achievement and enjoyment in the other three quadrants of one's life is critical as well (Clark, 2000; Clarke, Koch \& Hill, 2004). The provision of childcare, eldercare, healthcare education care and other social service facilities to employees is paramount to the development and management of employee talent, skills and knowledge desired to improve their productivity.

Due to modern demands, more companies offered other benefits. Items such as company cars and a set number of free flights per year were normal for many companies. A four-day workweek as well as flexible hours and casual dress were common also. These benefits were primarily instituted to attract, motivate and retain a superior quality workforce. While many leading companies have extensive work-life programs, policies and practices, most have not yet changed their organizational cultures to support employees and managers who want to use work-life options (Greenhaus, Collins \& Shaw, 2003; Harris, 2007; Hayman, 2010). This philosophy appeared to be widespread in the 1990's, because work-life programs were in place, however if an employee wanted to be a manager, they were not allowed to work four day weeks.

Many corporations can no longer afford the monetary compensation they were handing out in the 1990's. However, with layoffs commonplace, these companies are looking to use their inexpensive recession benefits as tools to build loyalty and encourage teamwork with coworkers (Janice, 2004). Through these benefits, along with the traditional programs such as insurance and retirement plans, managing the remaining workforce after layoffs is vital. When the struggling economy turns around, the remaining employees will be responsible for bringing their respective companies "back to life", and back to a competitive force.

Vacation time is one area where the federal government has not weighed in with significant legislation. While most companies offer two weeks to new employees as a standard, each company can determine their own vacation policy. Therefore, disparities exist between vacation policies which are a source of competitive advantage. Typically, those employees with more seniority receive more vacation time (Harris, 2007; Hayman, 2010). Many companies offer the ability to accrue more vacation time in relation to the length of service. However, very few companies offer additional vacation time as a reward for good work.

Paternity leave is an issue that has recently received attention with the passing of the Family and Medical Leave Act. The intent of the Family and Medical Leave Act was to standardize the rights employees have to family leave. While originally intended to protect working mothers, the scope of the law was expanded to incorporate the changing needs of the American family (Greenhaus, Collins \& Shaw, 2003; Harris, 2007). As more of the population deals with elderly parental care, single parenting, the mandated leave affords a broad spectrum of demographic groups' coverage. As a result, many companies offer childcare benefits as an enticement to workers with families. The methods used to support workers are varied and few concepts are universally accepted (Huang, Hammer, Neal, \& Perrin, 2004). In-house childcare facilities, after school programs, subsidized childcare, and referral services are all ways that employers use to help employees care for their children. One common program is childcare spending accounts. 
These programs take advantage of tax relief provided by the federal government and are offered by over 90 percent of employers (Halpern, 2005).

Employees at times are married to their jobs forgetting other aspects of life. These employees need some programs of reminders. Self-care includes any intentional actions taken to care for the various aspects of life other than employment. While self-care is important across the lifespan and can take different forms, it is often overlooked, undervalued and misperceived (Huang, Hammer, Neal, \& Perrin, 2004). This is especially the case in many working life, a time when there are many competing demands and expectations for success. Creating a sense of balance between work and other aspects of life values, can be challenging, particularly given the nature of working nature (Mesmer-Magnus \& Viswesvaran, 2005).

Excellent coverage and preventive care, proactive programs, and a range of fitness resources can help keep employees healthy and happy. From compressed workweeks, flextime, and alternate start times to telecommuting and part-time and job share positions, each business unit has a range of options for you to explore. Providing a variety of rideshares and transportation programs that make getting to work less of a hassle (Moen, \& Roehling, 2005). This can make it easy for employees to strike a healthy Quality of Work Life are a difficult challenge even in the best of times.

Finally, it is expected that performance would be maintained or improved to higher scales. Employees are at their desks for an average of about five hours every day, and companies are paying for that time (SPRING Singaore, 2011). However, often the results of an employee's work vs. time-spent do not exactly match up. A model employee that seems perfectly productive can turn out to be one of the worst offenders. Companies are aware that to realize this and are starting to allocate resources for performance management, which focuses on the performance of employees and ensuring their output aligns with the company's goals. For example, a study by Herb 2015, only 8 percent of companies believed their performance management process drove business value. "This year, the importance of performance management rose significantly, with 75 percent of respondents rating it an 'important' or 'very important' issue, up from 68 percent last year (Hung, 2016).

\section{CONCEPTUAL FRAMEWORK}

The independent variables for work life balance (QWL) that included: Agility working, social service care, self-care program and career care program were explored to establish their influence on performance management in Kenya. This study argues that Quality of Work Life is a key factor that affects performance management. The effect of Quality of Work Life on performance managementcan be direct or through its effect on family balance as seen on Figure 1.1, below.

\section{Independent Variable (IV)}

\section{Dependent Variable (DV)}

\begin{tabular}{|l|l|}
\hline Work Life Balance & \\
- Agility Working Environment & Performance \\
- Social Service Care & Management \\
- Self Care Program & Pareer Care Program \\
- Employee Productivity \\
- Physical Growth
\end{tabular}

Figure 1.1: Conceptual Framework

Qualty of work life, in its broadest sense, is defined as a satisfactory level of involvement or 'fit' between the multiple roles in a person's life (Clarke, Koch \& Hill, 2004). Work/life imbalance 
is when the pressures from one role make it difficult to comply with the demands of the other. (Greenhaus \& Beutell, 1985). Employees who experience increased stress due to work/life conflict and decreased perceptions of control over their work and non-work demands are less productive, less committed to, and satisfied with, their organisation and more likely to be absent or leave the organisation (Grant-Vallone \& Ensher, 1998).

The nature of work, such as its routinization, supervision, and complexity, has been linked casually to an individual's sense of control and depression (Kohn \& Schooler, 1982) Individuals experiencing interference between work and personal lives are also significantly more likely to suffer from reduced psychological well-being and physical health (Howard \& Donofrio, 2001). Perceived balance between work and social roles usually is leading to life satisfaction. Work-family balance was found to predict well-being and the overall quality of life (Fisher,2002; Greenhaus, Collins \& Shaw, 2003) .

On the other hand, failure to achieve balance was associated with reduced job and life satisfaction (Allen, Herst, Bruck, \& Sutton, 2000), decreased well-being and quality of life (Grant Vallone \& Donaldson, 2001; Noor, 2004) as well as increased stress (Burke, 1988) and impaired mental health (Beatty, 1996; Grzywacz \& Bass, 2003), Well-being is a broadly defined as the overall quality of an employee's experience and functioning at work including physical and psychological dimensions (Warr, 1987). The well-being of employees is in the best interest of communities and organanizations since the average adult spends most of her or his life working and almost fifth to a quarter of the adult life satisfaction can be accounted for satisfaction with work (Campbell,Converse,\& Rodgers, 1976).

Research shows that employee well-being is an important concern for organizations and that employee well-being has a significant impact on the performance and survival of organizations by affecting costs related to illness and health care (Danna \& Griffin,1999), absenteism, turnover (Spector, 1997), and job performance (Judge at.al.,2001; Wright \& Cropanzano, 2000). Additionally, the World Health Organisation's 2005 Mental Health Action Plan for Europe has called for an improvement of employee mental health and has made specific recommendations for the provision of mental health care services in the workplace. (WHO, 2005)

Performance management is a challenge to most modern organisations. The desire to maintain steady performance is not always automatic. However, use of many factors such as Work life balance has become widely recognized as an important contributor to performance management, helping firms meet the challenges of an increasingly competitive and dynamic environment (Monczka et al., 2000). These pressures have driven companies toward forming closer relationships with a work life environment (Cousins, 1999).

The present study offers a new perspective and suggests an individual approach to assessing the quality of work life based on the measurement, for each health worker, of a specific range of wishes, hopes, and expectations on which he bases the evaluation of his own work life. The objective is to investigate the quality of work life indicators in the department of health at the Ministry of health.

\section{Research Gaps}

Although much has been done to establish the causes of the Career Care Programs at work places, the literature on quality of work life in the public sector is largely lacking, very little has been done in terms of the effects of quality of work life on employee Career Care Programs in the public sector. Apart from that, literature indicated that not many studies have been done in 
Kenya in relation to effects of quality of work life on employee Career Care Programs. Even those literature from private sector discusses less on the link between agile work environment, performance management and Social Service Care hence there is need of research to be done in the area therefore this study was important in that it added value in the academic literature and knowledge by closing these gaps that have been identified in the above literature.

\section{Materials and Methods}

This study was a descriptive survey study design which included combined qualitative and quantitative research methodologies. This was important since the study focused on the present state of target population. The study used this design because in this research, it was possible and isolate or control other variable factors while examining one or more of them. A part from that, the data collection included attitudes, ideas, comments, opinions of respondents on the proposed problem of study. (Sprawl, 2000) recommends use of case study technique for research where data include public opinions, attitudes, and ideas on the problem of investigation. It was a descriptive case study because it investigated, described, explored and analyzed any relationships between variables of study.

The study was carried out in the public institutions of Kenya, questionnaires were used targeted population was 300 employees and a sample size of 180 participants was selected. The top level management included for the rest of the levels. Stratified sampling technique was used. The study utilized both quantitative and qualitative research methodologies. Following this, appropriate test items were developed. These questionnaires for piloting were not part of the actual sample. Pre-testing helped to establish the reliability of the instruments by comparing the responses of the respondents for the same items. The items that seemed to elicit responses that had wide variations among the respondents were improved so as to enhance their reliability. On the other hand, items whose responses were almost similar were retained without making further changes. The researcher organized and classified the data collected in particular on completed questionnaire form. Incomplete forms were classified as invalid. After classifying, the data were entered in computer using (SPSS) statistical package for social sciences ready for analysis, before which the data were presented using tables, charts and frequency findings.

The items were measured by a 5-point Likert-scale, which ranges from strongly disagree (1) to strongly agree (5). Reliability analysis was subsequently done using Cronbach's Alpha which measures the internal consistency to establish if certain items within a scale measure the same construct.

The quality of work life depends on organizational conditions, thinking modes and their effect on staff welfare. Glason (1982) has examined some variables such as satisfaction, attention, health and safety. He concluded that the experience of quality of work life occurs when staff's competence is respected. This is based on three main sources: 1- Effect of work environment on employees, 2- the extent of work responsibility by employees 3- employees' level of experience coordination in work environment. So all of research finding emphasized on the effectiveness of quality of work life on the employees' performances, but the environment of two types of theoretical and technical ministry's in Iran were the same because both types of ministry's were public secondary ministry's.

\section{CONCLUSIONS OF THE STUDY}

That research related to the quality of work life has investigated its relationship with the variables such as ministry's effectiveness, performance, principals and decision-making 
methods. There is a dearth of research, though, with regard to comparing the quality of work life in different types of ministry's.

The results with regard to fair and adequate payment shows that in employees' opinion this component is lower than the average and their salary is not satisfactory and is not associated with their job. This causes job dissatisfaction among employees. It is quite clear that the development and prosperity of a society is related to the growth of its human resources. As a consequence, rethinking about the employees' salaries and adjusting them with other professions (though has a financial burden for governments) would lead to efficiency.

The research results related to other components of the quality of work life indicate that from the represents' point of view their work environment and their ministry's are at the moderate level. Investment to raise employees' health and safety in order to promote the health level of organization would lead to higher efficiency of the organization. Perhaps the reason why employees' point of view with regard to the safety of ministry's is moderate has its root in the old structure of ministry's and lack of facilities in them. Improving capabilities to provide individual development opportunities, increasing chances of utilizing acquired skills, job security and income, creating employment promotion system, in-service employee education, creating opportunities for employees' studies and training can help employees to empower themselves professionally.

Considering employees' condition of living and providing opportunities for leisure and study for higher education can motivate them and increase their motivation and efficacy. Mutual trust and confidence between employees would affect their motivation and the educational system. High social dependence among high ministry's employees in Kurdistan is desirable and effective in relation with ministry's health and fruitfulness.

Results from other components, that is, the amount of development of human resources, shows that the possibility of using skills, self-control and self-management and access to information related to field of work for planning are at an acceptable rate for employees who work in the province of Kurdistan. Although education has been successful in developing human resources, more attention to this issue is required.

\section{RECOMMENDATIONS}

The study recommends that Quality of work life (QWL) programs incorporate principles of job enrichment and socio-technical enrichment in a comprehensive effort to improve the quality of the work environment. QWL programs especially seek to integrate employee needs and wellbeing with the organisation's desire for higher productivity

And that exact meaning of quality circles can vary from organisation to organisation and country to country. Quality circles usually consist of small groups of five to ten workers who meet on a regular basis. The objective is to identify problems as a group, process suggestions and examine alternatives for improving (at relatively low cost) productivity, raising product and service quality, and increasing worker satisfaction.

Job analysis is a fundamental HRM activity. It is the process whereby jobs are studied to determine their tasks, duties and responsibilities, their relationships to other jobs, the conditions under which work is performed and the personal qualities required for satisfactory performance. The major job analysis data collection methods include observation, interview, questionnaire, employee diary, critical incident reporting and competency profiling. The products of job analysis are job descriptions and job specifications: job descriptions provide a 
written summary of the duties and responsibilities of the position; and job specifications focus on the personal characteristics and qualifications that are required to successfully perform the job. Job design identifies what work must be performed, how it will be performed, where it is to be performed and who will perform it.

QWL programs represent a comprehensive effort to improve the quality of the work environment by integrating employee needs and wellbeing with the organisation's need for higher productivity. Quality circles attempt to overcome job specialisation by giving employees the opportunity to participate in the management of their jobs instead of modifying the job content. Industrial democracy is often equated with employee participation. Industrial democracy involves a redistribution of power in an organisation whereas employee participation schemes (such as quality circles) do not. Industrial democracy is subject to controversy and management resistance whereas employee participation schemes, while also controversial, appear to have a greater chance of acceptance.

\section{References}

Abercromby, M. (2007). A Report on the Importance of Work-Life Balance.

Allen, T. D., Herst, D. E. L., Bruck, C. S., \& Sutton, M. (2000). Consequences associated with work-tofamilyconflict: A review and agenda for future research. Journal of Occupational Health Psychology, 5(2), 278-308.

Allen, K.P. (2009). "Managing Work-life Balance ". The Professional Manager 34 (1).

Allen and Russell (2009) Making Employment Equity Programmes work for women. Canadian Public Policy, 28, 85-100.

Ansari S., Chimani K., Baloch R. A., and Bukhari S. F., (2015). Impact of Work Life Balance on Employee Productivity: An Empirical Investigation from the Banking Sector of Pakistan. Information and Knowledge Management www.iiste.org ISSN 2224-5758 (Paper) ISSN 2224-896X (Online)Vol.5, No.10, 2015

Balmforth, K., \& Gardner, D. (2012). Conflict and facilitation between work and family: realizing the outcomes for organizations. New Zealand Journal of Psychology, 35(2), 69-76.

Boca D, Yuri D, (2011). The Mismatch between Employment and Child Care in Italy: The Impact of Rationing. Journal of Population Economics, 20(4), 805-832.

Bond, F. W., \& Bunce, D. (2010). Mediators of change in emotion-focused and problem-focused worksite stress management interventions. Journal of Occupational Health Psychology, 5(1), 156-163. doi: 10.1037//10768Q98 1.1.156.

Bond, F. W. (2010) 'How can job design improve worker well-being and workplace performance? 'Institute for Employment Studies, 40th Anniversary Conference.

Bond F. W., (2009), Time pressure as a stress factor", Society and leisure, Vol. 21, No. 2, Autumn 1998, Presses de l'Université du Québec. pp. 491-511.

Brough, P, O'Driscoll, MP and Biggs, A ( 2015). Parental leave and work-family balance among employed parents following childbirth: An exploratory investigation in Australia and New Zealand, Kotuitui: New Zealand Journal of Social Sciences Online, 4(1): 71-87.

Cochran, W. G. 1963. Sampling Techniques, $2^{\text {nd }}$ Ed., New York: John Wiley and Sons, Inc.

Casper, W. J., \& Harris, C. M. (2011). Work-life benefits and organizational attachment: Self-interest utility and signaling theory models. Journal of Vocational Behavior, 72, 95-109.

Chow, I. H., \&Keng-Howe, I. C. (2013). The effect of alternative work schedules on employee performance. International Journal of Employment Studies, 14(1),105-130.

Clark SC (2000) Work/family border theory: a new theory of work/family balance. HumRelat 53:747-770

Clarke MC, Koch LC, Hill EJ (2004) The work-family interface: differentiating balance and fit. Fam Consum Sci Res J 33:121-140

De Bruin \& Dupuis, (2010) Bosses' perception of family-work conflict and women's Promo ability: Glad ceiling effects. Academy of Management Journal, 52, 5, 939-957. 
Delecta, P, (2011). Work Life Balance. International Journal of current Research, 3(4),186-188.

Edwards, J. R., \& Rothbard, N. P. (2000). Mechanisms linking work and family: Clarifying the relationship between work and family constructs. Academy of Management Review, 25, 178-199.

Ezra M, Deckman M, (2014). Balancing Work and Family Responsibilities: Flextime and Child Care in the Federal Government. Jstor, 56(2), 174-179

Fagan J, Laughlin L, (2014). Taking Pressure off Families: Child-Care Subsidies Lessen Mothers' Work-Hour Problems. Journal of Marriage and Family, 68(1), 155-171.

Gay, L. (2002). Education Research competencies for analysis and application (4th ed). Macmillan publishers: New York, USA.

Gay, L.R. \& Diehl, P.L. (1992). Research Methods for Business and Management. New York: Macmillan Greenhaus JH, Collins KM, Shaw JD (2003) The relation between work-family balance and quality of life. J Vocat Behav 63:510-531

Grzywacz JG, Bass BL (2003) Work, family, and mental health: testing different models of work family fit. J Marriage Fam 65:248-262

Grzywacz JG, Carlson DS (2007) Conceptualizing work-family balance: implications for practice and research. Adv Dev Hum Resour 9:455-471

Grzywacz JG, Marks NF (2000) Reconceptualizing the work-family interface: an ecological perspective on the correlates of positive and negative spillover between work and family. J Occup Health Psychol 5:111-126

Halpern, D. (2005). Psychology at the intersection of work and family. American Psychologist, 60, 397-409.

Harris G, (2007). Is Job Sharing Worthwhile? A Cost-Benefit Analysis in UK Universities. Jstor, 33(1), 29-38

Hayman, J (2010).Flexible work schedules and employee well-being, New Zealand Journal ofEmploymentRelations (Online), 35(2): 76-87.

Huang, Y., Hammer, L., Neal, M., \& Perrin, N. (2004). The relationship between work-to-family conflict and familyto-work conflict: A longitudinal study. Journal of Family and Economic Issues, 25, 79- 100.

Janice Johnson, (2004). Flexible working: Changing the Manager's role. Management Decision, 42(6), 721-725.

Jones F, Burke RJ, Westman M (2006) Work-life balance: a psychological perspective. Psychology Press, New York, NY

Kamau, J. M., Mukaya S. O., and Wagoki J., (2013), Work-Life Balance Practices on Employee Job Performance at Eco Bank Kenya. European Journal of Business and Management www.iiste.org ISSN 2222-1905 (Paper) ISSN 2222-2839 (Online) Vol.5, No.25, 2013

Kerlinger (2009) Research Strategies 2nd Edition, Published By Harvard Business School Press New Jersey, U.S.A Kiger, (2005), Life Balance: Multidisciplinary Theories and Research. Bethesda, MD: AOTA Press/Slack Publishers. 2005

Kinnunen U, Feldt T, Geurts S, Pulkkinen L (2006) Types of work-family interface: well-being correlates of negative and positive spillover between work and family. Scand J Psychol 47: 149-162

Kinnunen U, Mauno S, Geurts S, Dikkers J (2005) Work-family culture in organizations: theoretical and empirical approaches. In Poelmans SAY (ed) Work and family: an international research perspective. Lawrence Erlbaum, Mahwah NJ, pp 87-120

Kirrane and Buckley, (2008) "Work-Family Spill over and Daily Reports of Work and Family Stress in the Adult LabourForce"Family Relations. 51: 28-36

Kohinur A, (2013). Determinants of Work-life Balance of Women Professionals: Evidence from Bangladesh. International Journal of Applied Research in Business Administration and Economics, 2(2), 2830.

Kothari, C. R. (2009). Research methodology: Methods and Techniques. 2 Ed, New Age International.

Kothari, C. R. (2004). Research Methodology. New Delhi: New Age international.

Leblebici, D. (2012). Impact Of Workplace Quality On Employee's Productivity: Case Study Of A Bank In Turkey. Journal of Business, Economics, 1, 1.

Lyons, F. H. \& Ben-Ora, D. (2006) Total Rewards Strategy: The Best Foundation of Pay for Performance. Compensation \& Benefits Review, Vol. 34, No. 2, pp. 34-40. 
McDonald, D.A., \& Almeida, D.M. (2004). The interweave of fatherís daily work experiences and fathering behaviors, Fathering, 2, 235- 251.

Mesmer-Magnus, J., \& Viswesvaran, C. (2005). Convergence between measures of work-to- family and family-towork conflict: A meta-analytic examination. Journal of Vocational Behavior, 67, 215-232.

Moen, P., \& Roehling, P. (2005), The Career Mystique: Cracks in the American Dream, Rowman \& Littlefield Publishes, Inc., New York.

Moen, P. \& Yu, Y. (2000). Effective work/life strategies: Working couples, working conditions, gender, and life quality. Social Problems, 47, 291-326.

Morrissey, TW and Warner, ME (2011). An exploratory study of the impacts of an employer-supported child care program, Early Childhood Research Quarterly, 26(3): 344-354.

Mugenda, M. O. and Mugenda A.G. (2003). Research Methods in Education: Quantitative and Qualitative Approach, Nairobi. Acts press

Mugenda, O. M. \& Mugenda, A. G. (2003). Research methods: Quantitative and qualitative Approaches. Nairobi: African Centre for Technology Studies.

Nancy R, L, (2003). Work Life Balance: Challenges and Situations. Society for Human Resource Management Research Quarterly, 2-4.

Ngambi H.C, (2004). Job Sharing and Employee Productivity: Two for the Price of One? Southern African Business Review, 8(2), 16-30

Ng'ang'a (2010). 'Quality of Work Life Practices among International Non-Governmental Organizations in the Health Sector in Kenya' (MBA thesis, University of Nairobi 2010)

Ngechu. M. (2004), Understanding the research process and methods. An introduction to research methods. Acts Press, Nairobi

Osano M. (2005), Simplified Research methodology, 3r Edition Oxford Press, Serial Number BR0006029FD3495 Presented to the University of Dar-salaam.

Oswald, A. (2012). The effect of working environment on workers performance: the case of reproductive and child health care providers in Tarime district (Doctoral dissertation, Muhimbili University of Health and Allied Sciences).

Paoli, P. and Merllié, D., (2001) Third European survey on working conditions 2000, European Foundation for the Improvement of Living and Working Conditions, Office for Official Publications of the European Communities, Luxembourg, 2001.

Payne, SC, Cook, AL and Diaz, (2012). Understanding childcare satisfaction and its effect on workplace outcomes: The convenience factor and the mediating role of work-family conflict, Journal of Occupational and Organizational Psychology, 85(2): 225-244

Persuhn P G, (2012). Working with People: Job sharing: Two Who Made It Work. The American Journal Of Nursing, 92(9), 75-80.

Peeters, M., de Jonge, J. Janssen, P., van der Linden, S. (2004). Work ñ home \interference, job stressors, and employee health in a longitudinal perspective. International Journal of Stress Management, 11, $305-322$.

Peeters, M., Montgomery, A. Bakker, A., \& Schaufeli, W. (2005). Balancing work and home: How job and home demands are related to burnout. International Journal of Stress Management, 12, 43-61.

Pierce, Jon L.; Dunham, Randall B (2012). The 12-Hour Work Day: A 48-Hour, Eight-Day Week. Academy of Management Journal, 35(5) 1087-1089.

Richardson M, (2014). Making Job Share Work: Australian Women Share their Success Secrets. Horizons Unlimited Pty Ltd.

Ronen, Simcha; Primps, Sophia B (2010). The Compressed Work Week as Organizational Change: Behavioural and Attitudinal Outcomes. Academy of Management Review, 6(1), 48-52.

Roscoe, J.T. (1975) Fundamental Research Statistics for the Behavioural Sciences, $2^{\text {nd }}$ edition. New York: Holt Rinehart \& Winston

Rudy Hung (2016). An annotated bibliography of compressed workweeks. International Journal of Manpower, $17(6 / 7)$ 
Schindler, D. R., \& Cooper, P. S. (2003). Business research methods. New Delhi: Tata

SPRING Singapore, (2011), A Guide to Productivity Measurement. Published by SPRING Singapore ISBN 978-9814150-27-9

Stanley EG, Gregory MM (2001) “Achieving World Class Supply Chain Alignment: Benefits, Barriers and Bridges.” A Compiled Research Report

T.Alexandra Beauregard, L. C. (2015). Making the link between work-life balance practices and organizational performance. Human Resource Management Review, 9-22

Thomas L. and Ganster D. (2013). Impact of family-supportive work variables on work-family conflict and strain: A control perspective. Journal of Applied Psychology, Vol.80, pp.6-15.

Thompson and Prottas, 2016: Relationships among organizational family support, job autonomy, perceived control and employee well-being. Journal of Occupational Health Psychology. 11(1):100-118.

Voydanoff P (2005) Toward a conceptualization of perceived work-family fit and balance: a demands and resources approach. J Marriage Fam 67:822-836

Wang, P., \&Walumbwa, F. (2010). Family-friendly programs, organizational commitment, and workwithdrawal:the moderating role of transformational leadership. PersonnelPsychology 60,397-427. 